\title{
ACADEMIC DISHONESTY IN TRADITIONAL AND ONLINE CLASSROOMS: DOES THE "MEDIA EQUATION" HOLD TRUE?
}

\author{
Erik W. Black \\ Doctoral Fellow and Candidate \\ The School of Teaching and Learning, The University of Florida
}

Joe Greaser

Graduate Student

The School of Teaching and Learning, The University of Florida

Kara Dawson

Associate Professor

The School of Teaching and Learning, The University of Florida

\begin{abstract}
Limited empirical research exists regarding the prevalence of academic dishonesty in the online classroom. This limited evidence supports the notion that factors contributing to academic dishonesty in the traditional classroom also apply to online courses. The purpose of this study is to explore the relationship between factors known to contribute to academic dishonesty in traditional courses with undergraduate students' perceptions of cheating in online courses.
\end{abstract}

1068 undergraduates enrolled in online courses completed a survey exploring factors known to contribute to academic dishonesty in face-to-face classes and their perception of their peers' level of cheating in online courses. Researchers employed bivariate correlations and multiple regression on data obtained from these students. Results suggest factors known to contribute to academic dishonesty in face-to-face classes have little influence in online courses, and results suggest that future research needs to consider whether students who engage in online learning have different ideas about what constitutes cheating.

\section{KEYWORDS}

Academic Honesty, Cheating, Distance Education, Survey, Undergraduate

\section{INTRODUCTION}

There is limited research regarding the actual prevalence of academic dishonesty in the online classroom; much of the existing body of research focuses on aspects of plagiarism $[1,2,3]$. There is reason to believe that much of what is known about academic dishonesty in the brick and mortar classroom may also apply to online courses. Indeed, people routinely respond to computer-mediated situations in the same way they respond to real world situations $[4,5]$. This phenomenon is frequently referred to as the "Media Equation" [4]. 
If students are exhibiting the same behavior in online courses that they exhibit in traditional classrooms, then instructors and designers of online courses have cause for alarm. A high percentage of students cheat in classroom-based courses $[2,6,7]$. Research suggests various personal and environmental factors that contribute to academic dishonesty $[2,8,9]$.

The purpose of this study is to explore the relationship between factors known to contribute to academic dishonesty in traditional courses with undergraduate students' perceptions of cheating in online courses.

Specifically, we explore the relationships between 1068 undergraduate students' perceptions of the amount of cheating occurring in their online courses and the following factors which have been shown to contribute to academic dishonesty in traditional classrooms: (1) the number of credits taken during the semester [10,11], (2) the number of hours spent weekly on the course [12], (3) the perceived learning as a result of the course [13] and (4) the perceived amount of interaction with the instructor [14]. As such, the following question guided this exploratory research: Is there a relationship between cheating in online educational environments and variables traditionally related to cheating in a traditional educational environment?

\section{METHOD}

\section{A. Participants}

The participants were 1068 undergraduate students enrolled in 12 completely online psychology courses at a Research 1 university. The average class size is 90, with a range from 8 to 312 and a standard deviation of 80 . The classes are populated primarily by 18-22 year-old undergraduate students from a variety of majors, with the largest concentration being psychology majors. Reviews of enrollment data have shown that students in these online courses are generally in later academic years and have higher GPA's.

\section{B. Instrumentation}

The instrument used to survey the population (Appendix A) was included as part of a question mid-term technical courseware evaluation. A more sound methodological approach to this research would have been to supply the survey at the end of the course, unfortunately, this was not logistically possible from an administrative standpoint. The first five survey questions dealt with aspects of student academic perceptions, two question offered students a free response option, these question asked students to report the number of credits in which they were currently enrolled and the amount of time they dedicated to classwork specific to the online course. Students responded to the remaining academic honesty questions via five-point Likert scales. The scales ranged from less likely (1) to more likely (5). The last two questions were free response items requesting student feedback regarding pedagogical and technical improvement of the courses offered to the population. It should be noted that the five point Likert scales limited the range of variability of student responses. While this is typically a concern with smaller data sets, the overall size of the sample $(\mathrm{N}=1068)$ reduced the impact of the limited variability. Because of the limited number of items constituting the survey and the multidimensional structure of the data, the calculated Cronbach $\alpha$ of .07 will be ignored.

It is important to note that the questionnaire employed did not explicitly seek information about respondent's propensity to cheat or habits of academic honesty or dishonesty. In order to avoid collecting data constituting social desirable answers, a concern prevalent with research in academic honesty [15], the researchers asked participants to gauge whether others within their online class were engaged in 
Academic Dishonesty in Traditional and Online Classrooms: Does the "Media Equation" Hold True?

academically dishonest practices. Research by Jordan [16] indicates that among cheaters, the perception that those around them are engaged in academically dishonest behavior is more prevalent then amongst those who do not engage in academically dishonest behavior.

\section{Data Collection}

After the fourth week of class, a link appeared on each course homepage titled, "Research Survey". The target page stated that participation was voluntary, and that all submissions were completely anonymous. In addition, there was a link to the questionnaire. The questionnaire was administered using the WebCT course management software's survey tool. The questionnaire was available for one week. At the end of the week, the results from each course were downloaded and the questionnaire and results were deleted from the course. Results were analyzed and interpreted post-hoc utilizing SAS Business Intelligence and Analytics Software [17]. Due to the post-hoc nature of analysis, significance tests were two-tailed in nature, resulting in a minor loss of power. Because of the size of the sample, this loss of power had no significant effect on the overall results of the study.

\section{Data Analysis}

This study investigated the relationship between the independent variables and the perception that others enrolled within the distance education class were engaging in academically dishonest behavior (cheating). Independent variables included: perceived learning, perceived interaction, contact hours and number of credit hours currently enrolled. For the purposes of the study, perceived learning was defined as the amount of learning taking place within the distance education course as compared to traditional classroom-based courses. Perceived interaction was defined as opportunities for interaction with the instructor and/or teaching assistant as compared to traditional classroom based courses. Contact hours were defined as the number of hours spent during an average week completing course work. The dependent variable of measure, perceived likelihood of cheating compared to traditional classroom based courses, was measured on a five-point Likert scale. Pearson product-moment correlation coefficients were utilized to determine correlations between variables. Multiple linear regression was employed to detect the significantly predictive effect of the independent variables on the dependent variable.

\section{RESULTS}

A review of descriptive statistics derived from the study (see table 1) reveals that students reported the perception that there was less cheating in online classes as compared to face to face classes (mean $=2.74$, $\mathrm{SD}=.95)$. Students also reported perceiving a higher level of learning as compared to face to face classes $($ mean $=3.32, \mathrm{SD}=1.00)$. Additionally, students reported perceiving a lower level of professor and TA interaction as compared to face to face classes (mean $=2.68, \mathrm{SD}=1.25)$. Pearson product-moment correlation among all variables were calculated, these results are reported in table 2. Multiple regression analysis of the sample $(\mathrm{N}=1068)$ showed that the interaction between the dependent variable (cheating) and the independent variables within a single block: contact hours, perceived learning, instructor interaction and contact hours were significant $\mathrm{F}(4,1068)=20.6, \mathrm{p}<.0001$. The model was able to account for $7 \%$ of the variance (adjusted $\mathrm{R}$ square $=.07,(95 \% \mathrm{CI}=4.1 \%, 9.9 \%)$. It is important to note that the effect sizes of each of the interactions are relatively small, thus significance in the case of each interaction may be attributed to the sample size. Table 3 details the results of the multiple regression. 
Table 1: Descriptive Statistics $(n=1068)$

\begin{tabular}{|l|l|l|}
\hline & Mean & $\begin{array}{l}\text { Standard } \\
\text { Deviation }\end{array}$ \\
\hline $\begin{array}{l}\text { Perceived } \\
\text { Cheating }\end{array}$ & 2.74 & .95 \\
\hline $\begin{array}{l}\text { Perceived } \\
\text { Learning }\end{array}$ & 3.32 & 1.00 \\
\hline $\begin{array}{l}\text { Perceived } \\
\text { Interaction }\end{array}$ & 2.68 & 1.25 \\
\hline $\begin{array}{l}\text { Contact } \\
\text { Hours }\end{array}$ & 3.36 & 2.26 \\
\hline Credits & 13.7 & 2.74 \\
\hline
\end{tabular}

Table 2: Correlations Between Variables for All Subjects $(n=1068)$

\begin{tabular}{|l|l|l|l|l|l|}
\hline & Cheating & Learning & Interaction & Contact & Credits \\
\hline $\begin{array}{l}\text { Perceived } \\
\text { Cheating }\end{array}$ & 1.00 & $-.20^{*}$ & $-.09^{*}$ & $-.18^{*}$ & -.01 \\
\hline $\begin{array}{l}\text { Perceived } \\
\text { Learning }\end{array}$ & $-.20^{*}$ & 1.00 & $.37^{*}$ & .04 & .03 \\
\hline $\begin{array}{l}\text { Perceived } \\
\text { Interaction }\end{array}$ & $-.09^{*}$ & $.37^{*}$ & 1.00 & .01 & -.02 \\
\hline $\begin{array}{l}\text { Contact } \\
\text { Hours }\end{array}$ & $-.18^{*}$ & .04 & .01 & 1.00 & $.10^{*}$ \\
\hline Credits & -.01 & .03 & -.02 & $.10^{*}$ & 1.00 \\
\hline
\end{tabular}

Table 3: Results of the Multiple Regression Analysis of Cheating and the Four Independent Variables $(\mathrm{n}=1068)$

\begin{tabular}{|l|l|l|l|l|}
\hline & $\boldsymbol{\beta}$ & $\begin{array}{l}\text { Standard } \\
\text { Error } \boldsymbol{\beta}\end{array}$ & $\mathbf{t}$ & Significance \\
\hline $\begin{array}{l}\text { Perceived } \\
\text { Learning }\end{array}$ & -.19 & .03 & -5.88 & $<.0001^{*}$ \\
\hline $\begin{array}{l}\text { Perceived } \\
\text { Interaction }\end{array}$ & -.02 & .02 & -.079 & .4302 \\
\hline $\begin{array}{l}\text { Contact } \\
\text { Hours }\end{array}$ & -.07 & .01 & -5.82 & $<.0001^{*}$ \\
\hline Credits & .004 & .01 & .38 & .7044 \\
\hline
\end{tabular}

${ }^{*} \mathrm{p}<.05$, beta $=9.4$ (assumes most pessimistic variance assumption) 
Academic Dishonesty in Traditional and Online Classrooms: Does the "Media Equation" Hold True?

Table 4: Squared Partial Correlations Between Cheating and Four Independent Variables for All Subjects (n=1068)

\begin{tabular}{|l|l|l|}
\hline & $\begin{array}{l}\text { Squared } \\
\text { Semi-Partial } \\
\text { Correlation }\end{array}$ & $\begin{array}{l}\text { Squared } \\
\text { Partial } \\
\text { Correlation }\end{array}$ \\
\hline $\begin{array}{l}\text { Perceived } \\
\text { Learning }\end{array}$ & .0300 & .0300 \\
\hline $\begin{array}{l}\text { Perceived } \\
\text { Interaction }\end{array}$ & .0005 & .0005 \\
\hline $\begin{array}{l}\text { Contact } \\
\text { Hours }\end{array}$ & .0300 & .0300 \\
\hline Credits & .0001 & .0001 \\
\hline
\end{tabular}

Table 5: Pearson Product Moment Correlations: Cheating and Four Independent Variables for All Subjects (n=1068)

\begin{tabular}{|l|l|l|l|l|l|}
\hline & $\begin{array}{l}\text { Perceived } \\
\text { Cheating }\end{array}$ & $\begin{array}{l}\text { Perceived } \\
\text { Learning }\end{array}$ & $\begin{array}{l}\text { Perceived } \\
\text { Interaction }\end{array}$ & Contact & Credits \\
\hline $\begin{array}{l}\text { Perceived } \\
\text { Cheating }\end{array}$ & 1.00 & $-.2^{*}$ & $-.09^{*}$ & $-.18^{*}$ & -.01 \\
\hline $\begin{array}{l}\text { Perceived } \\
\text { Learning }\end{array}$ & $-.2^{*}$ & 1.00 & $.37^{*}$ & .05 & .03 \\
\hline $\begin{array}{l}\text { Perceived } \\
\text { Interaction }\end{array}$ & $-.09^{*}$ & $.37^{*}$ & 1.00 & .013 & -.02 \\
\hline $\begin{array}{l}\text { Contact } \\
\text { Hours }\end{array}$ & $-.18^{*}$ & .04 & .01 & 1.00 & $.10^{*}$ \\
\hline Credits & -.01 & .03 & -.02 & $.10^{*}$ & 1.00 \\
\hline
\end{tabular}

\section{A. Measure I: Perceived Cheating and Perceived Learning}

The data indicates that a minor inverse relationship between perceived cheating and perceived learning when other factors are held constant. This indicates that those who perceived they were learning more within their classes were less likely to perceive that there is cheating occurring within their online course. While the findings were significant, the correlation between the two variables was relatively small at -.2 (see table 5). Application of multiple regression reveals a squared semi-partial correlation of .030 (see table 4). The squared partial correlation measures the association between the dependent variable, cheating, and perceived learning with all other variables held constant. Our analysis indicates that of the variance in cheating not associated with instructor interaction, credit hours and contact hours, on average, $3 \%$ is associated with perceived cheating.

\section{B. Measure II: Perceived Cheating and Perceived Instructor Interaction}

The data indicates that a minor inverse relationship exists between interaction with instructors and faculty and cheating when other factors are held constant. Meaning that, students who had more interactions with their instructors and faculty were less likely to feel cheating was occurring within their online course. While the findings were statistically significant, it is important to note that the spurious correlation between these two variables is extremely small at -.09 (see table 5). Application of multiple regression reveals a squared partial correlation of .0005 (see table 4). The squared partial correlation measures the association between the dependent variable, cheating, and instructor interaction with all other variables 
held constant. Our analysis indicates that of the variance in perceived cheating not associated with learning, credit hours and contact hours, on average .054 is associated with instructor interaction.

\section{E. Measure III: Perceived Cheating and Contact Hours}

The data indicates that a minor inverse relationship between the perceived cheating and contact hours. This indicates that those who spent more time engaged in course oriented activity were less likely to perceive that cheating was occurring within their online course. While the findings were significant, the spurious correlation between the two variables was relatively small at -.18 (see table 5). Application of multiple regression reveals a squared partial correlation of .030 (see table 4). The squared partial correlation measures the association between the dependant variable, perceived cheating, and contact hours with all other variables held constant. Our analysis indicates that of the variance in perceived cheating not associated with instructor interaction, credit hours and perceived learning, on average 3\% is associated with instructor interaction.

\section{F. Measure IV: Perceived Cheating and Credit Hours}

The data indicates that an extremely small inverse but non-significant relationship (at the .05 level) between perceived cheating and the number of credit hours that a student was enrolled in, when other factors are held constant. This indicates that there is no relationship between the number of credit hours that a student enrolls in and perceptions of cheating within an online course.

\section{DISCUSSION}

The results of this study represent significant findings that deviate from traditional views regarding cheating in online courses. Our research suggests ideas regarding the factors that influence academic dishonesty in an online course need to be adjusted. While our results indicated that the independent variables accounted for a statistically significant amount of variance within the dependent variable, this amount was relatively small (adjusted R square $=.07$ ).

Kennedy, Nowak, Thomas and Davis [18] have asserted that distance learning environments provide and promote opportunities for academic dishonesty to a degree greater then found in traditional learning environments. The data reported within this study directly refutes this claim, instead indicating that a vast majority of students $(81 \%)$ feel that cheating within their online course is no more prevalent then cheating within a traditional course. These results concur with the idea that beliefs regarding the rampant nature of cheating within online learning environments are based on anecdotal evidence at best and an argumentum ad populum at worst [19]. While this may be an encouraging notion, it is important to remember that regardless of whether in face-to-face classrooms or online, today's college students are engaging in academically dishonest practices with increasing prevalence [20,21, 22].

Ultimately, there may be the need to consider whether students engaged in online education have a fundamentally different perception of what does and does not constitute cheating compared to those in traditional educational environments.

\section{CONCLUSIONS}

Our findings were unable to directly substantiate motivations for cheating within an online learning environment. Our supposition was that the factors that influence academic honesty within traditional 
Academic Dishonesty in Traditional and Online Classrooms: Does the "Media Equation" Hold True?

learning settings would also have significant influence and effect on academic honesty in online learning environments. This hypothesis did not hold true, providing an opportunity to question Reeves and Nass's [4] "media equation" phenomenon. Based on the results of the study it is appropriate to evaluate whether online students define cheating in the same manner as those engaged in traditional educational environments. Additional studies to gauge this understanding are needed. In addition, qualitative analysis should be employed in order to gain a comprehensive perspective regarding measurable constructs that could be utilized within a valid and reliable instrument to obtain a measure academic honesty in online educational environments.

\section{ABOUT THE AUTHORS}

Erik Black and Joe Greaser are graduate students in the University of Florida's School of Teaching \& Learning. Kara Dawson is an Associate Professor in the University of Florida College of Education.

\section{REFERENCES}

1. Campbell, C.R., C. O. Swift \& L. T. Denton. Cheating goes hi-tech: Online term paper mills. Journal of Management Education 24(6): 726-744, 2000.

2. Ercegovac, Z. \& J. Richardson. (2004). Academic dishonesty, plagiarism included, in the digital age: a literature review. College \& Research Libraries 65(4): 2004.

3. Sterngold, A. Confronting plagiarism: How conventional teaching invites cybercheating. Change 36: 2004. Retrieved March 24, 2007, from InfoTrac database.

4. Reeves, B. \& C. Nass. The Media Equation : How People Treat Computers, Television, and New Media Like Real People and Places. Stanford, CA: Center for the Study of Language and Inf; Reprint edition, 2003.

5. Ferdig, R. E. \& P. Mishra. Emotional responses to computers: experiences in unfairness, anger, and spite. Journal of Educational Multimedia and Hypermedia 13(2): 143-162, 2004.

6. McCabe, D. L., L. K. Trevino \& K. D. Butterfield. Dishonesty in academic environments: The influence of peer reporting requirements. The Journal of Higher Education 71(1): 2001.

7. Scanlon, P. M. Student online plagiarism: How do we respond? College Teaching 51(4): 161-5, 2003.

8. Tanner, C. A. Moral decline or pragmatic decision making?: Cheating and plagiarism in perspective. Journal of Nursing Education 43(7): 291-2, 2004.

9. Underwood, J. \& A. Szabo. Academic offenses and e-learning: Propensities in cheating. British Journal of Educational Technology 34(4): 467-77, 2003.

10. Kerkvliet, J. \& C. L. Sigmund. Can we control cheating in the classroom? Journal of Economic Education 30(4): 331, 1999.

11. Whitley, B. E. Factors associated with cheating among college students: A review. Research in Higher Education 39(4): 1998.

12. Franklyn-Stokes, A. \& S. E. Newstead. Undergraduate cheating: Who does what and why? Studies in Higher Education 20(2): 159-172, 1995.

13. Wryobeck, J. M., B. E. Whitley \& E. Bernard. Educational value orientation and peer perceptions of cheaters. Ethics \& Behavior 9(3): 1999.

14. Born, A. D. Teaching tip: How to reduce plagiarism. Journal of Information Systems Education 14(3): 2003.

15. Sudman, S. \& N. Bradburn. Response effects in surveys: A review and synthesis. Chicago: Aldine, 1974.

16. Jordan, A. E. College student cheating: The role of motivation, perceived norms, attitudes and knowledge of institutional policy. Ethics \& Behavior 11(3): 2001. 
17. SAS. SAS Business Intelligence and Analytics Software, 2006. Retrieved November 9, 2006 from http://www.sas.com/.

18. Kennedy, K., S. Nowak, J. Thomas \& S. Davis. Academic dishonesty and distance learning: Student and faculty views. The College Student Journal 34(2): 309, 2000.

19. Baron, J. \& S. M. Crooks. Academic integrity in web based distance education. TechTrends 49(2): 40-45, 2005.

20. McCabe, D. L. \& L. K. Trevino. What we know about cheating in college. Change 28(1): 28-34, 1996.

21. McCabe, D. L. \& W. J. Bowers. Academic dishonesty among male college students: A thirty-year perspective. Journal of College Student Development 35(1): 3-10, 1994.

22. McCabe, D. L. \& L. K. Trevino. Academic dishonesty: Honor codes and other contextual influences. Journal of Higher Education 64(5): 522-538, 1993.

\section{APPENDIX A}

Dear Student,

We at the Psychology Department would like to ensure that we are serving your educational needs effectively in our web-based courses. In order to help us do so, we would greatly appreciate you taking just 2-3 minutes to give us your feedback on these important questions.

1. What is the total number of credit hours you are currently enrolled in?

2. Compared to classroom-based courses I have taken in psychology, my experience is that the students in this online course are:
a. 1 = Less likely to cheat then in face to face courses
b. 2
c. 3 = As likely to cheat as in face to face courses
d. 4
e. 5 = More likely to cheat then in face to face courses

3. Compared to classroom-based courses I have taken in psychology, I am learning...
a. $1=$ Less then in face to face courses
b. 2
c. $3=$ As much as in face to face courses
d. 4
e. $5=$ More then in face to face courses

4. Compared to other regular on-site courses I have taken in psychology, my experience is that in this online course the opportunities for interaction with the instructor and TA are:
a. 1 = Less frequent than in face to face courses
b. 2
c. $3=$ As frequently as in face to face courses
d. 4
e. 5 = More frequent than in face to face courses

5. How many hours a week do you spend, on average, completing course work (include ALL activities)? 